\title{
Rozdział 7
}

\section{Wpływ polityki monetarnej na strukturę kapitałową przedsiębiorstw w Polsce}

Konrad Szydtowski*

\section{Wprowadzenie}

Jednym z kluczowych problemów zarządzania finansami przedsiębiorstw jest kształtowanie właściwej struktury kapitałowej. Struktura ta jest pochodną stosowanych strategii w zakresie doboru i wykorzystania poszczególnych źródeł oraz instrumentów finansowania działalności bieżącej i inwestycyjnej. Decyzje oraz działania podjęte w tym zakresie znajdują swoje odzwierciedlenie w poziomie ryzyka finansowego, koszcie kapitału, obciążeniach wyniku finansowego, a w konsekwencji - w rentowności oraz rynkowej wartości przedsiębiorstwa.

O wadze podjętego zagadnienia badawczego może świadczyć to, że pomimo wielu powstałych teorii oraz badań prowadzonych w tym zakresie jak dotąd nie powstał jeszcze model optymalnej struktury kapitałowej charakteryzujący się uniwersalnością wykorzystania na gruncie działalności przedsiębiorstw. Jedną z przyczyn tego stanu rzeczy jest mnogość czynników determinujących strukturę kapitałową. Mogą mieć one charakter wewnętrzny, co wynika ze specyficznych cech danego przedsiębiorstwa i mikrootoczenia, w którym ono funkcjonuje, a także charakter zewnętrzny, odnoszący się do uwarunkowań makroekonomicznych.

W tym kontekście na szczególną uwagę zasługuje wpływ polityki monetarnej państwa na dobór oraz dostępność poszczególnych źródeł finansowania, a tym samym na kształtowanie struktury kapitałowej przedsiębiorstwa. Tematyka ta wydaje się mieć kluczowe znaczenie, biorąc pod uwagę istotny wpływ polityki monetarnej na podaż i koszt kapitału, kształtowanie się kursów walutowych, dostępność

* Uniwersytet Warmińsko-Mazurski w Olsztynie, Wydział Nauk Ekonomicznych, Katedra Finansów i Bankowości, ul. Oczapowskiego 4; 10-719 Olsztyn, e-mail: szydlowski.k@uwm.edu.pl 
kredytu czy też inne parametry uwzględniane w procesie planowania finansowego przedsiębiorstw.

Celem niniejszego opracowania jest próba określenia wpływu polityki monetarnej państwa na decyzje podejmowane w obszarze zarządzania strukturą kapitałową przedsiębiorstw. Zakresem przedmiotowym analiz objęty został jeden $\mathrm{z}$ kanałów transmisji impulsów polityki monetarnej - kanał stopy procentowej. Zakres czasowy badań to lata 2009-2014, a zatem okres dynamicznych zmian na rynkach finansowych, widocznych zarówno w obszarze polityki monetarnej, jak i w strategiach finansowych firm. Do analizy wykorzystano dane liczbowe Narodowego Banku Polskiego, Komisji Nadzoru Finansowego oraz Głównego Urzędu Statystycznego.

\subsection{Determinanty struktury kapitałowej przedsiębiorstw}

W literaturze przedmiotu wskazuje się wiele czynników determinujących strukturę kapitałową przedsiębiorstw. Stosuje się przy tym zróżnicowane kryteria klasyfikacyjne, w tym: możliwość reagowania przedsiębiorstwa na determinanty (czynniki endogeniczne, egzogeniczne), możliwość kwantyfikacji (ilościowe, jakościowe), wpływ na poziom dźwigni finansowej (zachęcające oraz zniechęcające do zwiększenia zadłużenia), czy sposób podejścia do wyodrębniania determinant

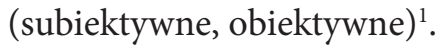

Często spotykanym kryterium jest podział na czynniki mikro- oraz makroekonomiczne. Pierwsza grupa obejmuje determinanty związane $\mathrm{z}$ samym przedsiębiorstwem, jak również relacje $\mathrm{z}$ otoczeniem konkurencyjnym, $\mathrm{w}$ tym $\mathrm{z}$ dostawcami, odbiorcami, konkurentami, wierzycielami czy jednostkami świadczącymi różnego rodzaju usługi na rzecz przedsiębiorstwa ${ }^{2}$. Czynniki o charakterze mikroekonomicznym obejmują więc takie aspekty, jak: wielkość i struktura majątkowa przedsiębiorstwa, forma organizacyjno-prawna, długość okresu funkcjonowania firmy na rynku, rentowność czy stosowana polityka dywidendowa. Ponadto są to: rentowność, stabilność sprzedaży, koszt i dostępność kapitału, elastyczność, poziom ryzyka operacyjnego i wiele innych. Jak widać, czynniki mikroekonomiczne mogą mieć charakter zarówno wewnętrzny, jak i zewnętrzny. Do grupy czynników wewnętrznych zalicza się także postawy właścicieli oraz kadry menedżerskiej. Ich

1 K. Łach, Kierunki badań nad determinantami struktury kapitału przedsiębiorstw w Polsce, Polskie Towarzystwo Ekonomiczne, Zeszyty Naukowe nr 12, Kraków 2012, s. 187-188.

2 J. Ickiewicz, Pozyskiwanie, koszt i struktura kapitału w przedsiębiorstwach, Szkoła Główna Handlowa w Warszawie, Warszawa 2004, s. 17. 
przejawem może być skłonność (bądź też awersja) do ryzyka finansowego, co znajduje odzwierciedlenie w podejmowanych decyzjach finansowych.

Odrębną grupę stanowią determinanty związane $\mathrm{z}$ makrootoczeniem przedsiębiorstwa. Chodzi tu m.in. o otoczenie ekonomiczne, społeczne, prawne, polityczne, demograficzne, technologiczne, jak też międzynarodowe. Fundamentalną rolę odgrywa otoczenie ekonomiczne, będące pochodną kondycji gospodarki danego kraju. Zależą od niego: stopa wzrostu gospodarczego, bilans płatniczy, stopa inflacji, zmienność kursów walutowych, relacje między importem a eksportem czy poziom deficytu budżetowego i jego relacja do PKB. Omawiana grupa obejmuje również system podatkowy państwa, poziom rozwoju rynku kapitałowego, jak również stopę bezrobocia ${ }^{3}$. Odrębnym czynnikiem makroekonomicznym jest polityka pieniężna banku centralnego, co zostało szerzej opisane w dalszej części rozdziału.

Biorąc pod uwagę problem zarządzania strukturą kapitałową przedsiębiorstwa, szczególną uwagę poświęca się problematyce asymetrii informacji. Zjawisko to dotyczy odmiennego zakresu wiedzy, jaką dysponują strony zawierające transakcje gospodarcze i postrzegane jest jako jedna z przyczyn nieefektywnej alokacji zasobów w gospodarce. Na gruncie działalności przedsiębiorstwa może ono występować zarówno pomiędzy właścicielami a kadrą zarządzającą, jak i pomiędzy właścicielami a wierzycielami. Wśród jego negatywnych skutków wskazuje się rezygnację $z$ efektywnych przedsięwzięć inwestycyjnych bądź też udostępnianie kapitału podmiotom nieefektywnym ${ }^{4}$. W obszarze zarządzania strukturą kapitałową kluczowe znaczenie ma sposób, w jaki przedsiębiorstwo pozyskuje środki finansowe - czy są to kapitały własne (wewnętrzne bądź zewnętrzne), czy też kapitały obce. W tym drugim przypadku nie bez znaczenia pozostaje również termin zapadalności wykorzystanych instrumentów dłużnych.

Problem ten znajduje odzwierciedlenie w teorii hierarchii źródeł finansowania, której twórcą jest S.C. Myers (The Pecking Order Theory). Zgodnie z tą teorią zjawisko asymetrii informacji występuje pomiędzy właścicielami oraz wierzycielami, jak również pomiędzy dotychczasowymi oraz nowymi inwestorami. W celu minimalizacji negatywnych skutków asymetrii informacji przedsiębiorcy, dokonując wyboru źródeł finansowania, stosują następującą kolejność: reinwestycja zysku, dług, instrumenty hybrydowe, emisja akcji ${ }^{5}$. Warto podkreślić, że zjawisko asymetrii informacji stanowi także przedmiot rozważań innych teorii dotyczących struktury kapitału, w tym: teorii sygnałów, teorii agencji czy teorii market timing.

3 N. Mokhova, M. Zinecker, Macroekonomic factors and corporate capital structure, „Procedia - Social and Behavioral Sciences" 2014, No. 110, s. 536-537.

4 J. Kubiak, Metody badania asymetrii informacji w przedsiębiorstwie w zakresie alokacji kapitału, „Gospodarka Narodowa” 2011, nr 4 (236), s. 48.

5 S.C. Myers, The Capital Structure Puzzle, „The Journal of Finance” 1984, Vol. XXXIX, No. 3, s. 581. 


\subsection{Mechanizm transmisji impulsów polityki pieniężnej banku centralnego w kontekście kształtowania struktury kapitałowej przedsiębiorstw}

Mechanizm transmisji impulsów polityki pieniężnej określa sposób oddziaływania władz monetarnych na decyzje podejmowane przez uczestników życia gospodarczego, jak też ich dalsze interakcje. Efektem tego procesu są zmiany takich zmiennych monetarnych, jak: pieniądz banku centralnego, wolne rezerwy płynności, podaż pieniądza, wolumen kredytów, poziom stóp procentowych, a także wartość aktywów finansowych o różnym stopniu płynności. Bank centralny, oddziałując na wskazane zmienne, kreuje tzw. impulsy pierwotne i decyduje w ten sposób o tworzonych przez banki operacyjne warunkach finansowych funkcjonowania podmiotów sektora pozabankowego ${ }^{6}$. Impulsy te kształtują zmiany podaży występujących w gospodarce instrumentów finansowych (np. kredytów, depozytów, papierów wartościowych), jak również zmiany cen, w tym stóp procentowych oraz kursów walutowych. Należy też wspomnieć o tzw. impulsach wtórnych, będących reakcją podmiotów rynkowych na impulsy pierwotne banku centralnego.

W literaturze przedmiotu wskazuje się również szereg innych klasyfikacji impulsów polityki monetarnej. Należą do nich: wpływ banku centralnego (impulsy bezpośrednie oraz pośrednie), sposób oddziaływania (mierzalne, niemierzalne), charakter polityki (restrykcyjne, ekspansywne), jak też horyzont czasowy, w ramach którego wyróżnia się impulsy krótko- i długoterminowe.

Mówi się także o różnorodności ścieżek przenoszących impulsy polityki pieniężnej, zwanych kanałami transmisji impulsów monetarnych. Do najczęściej opisywanych zalicza się kanał stóp procentowych, cen aktywów, kanały kredytowe (kredytów bankowych oraz bilansowy)oraz kanał kursu walutowego. Ponadto występują niestandardowe kanały transmisji impulsów polityki monetarnej. Chodzi tu o kanał kosztowy oraz kanał podejmowanego ryzyka (risk-taking channel) ${ }^{7}$.

Przedmiotem analiz w niniejszym rozdziale jest kanał stopy procentowej. W tym kontekście warto podkreślić wysoki stopień rozdrobnienia sektora przedsiębiorstw w Polsce. Zgodnie z danymi Polskiej Agencji Rozwoju Przedsiębiorczości w 2013 roku liczba przedsiębiorstw aktywnych wyniosła 1,77 mln, z czego małe i średnie przedsiębiorstwa stanowiły $99,8 \%{ }^{8}$. Efektem tak wysokiego rozdrobnie-

6 W. Przybylska-Kapuścińska, Impulsy i instrumenty monetarne w kształtowaniu relacji między bankiem centralnym a sektorem bankowym, „Ruch Prawniczy, Ekonomiczny i Socjologiczny” 2008, z. 2, s. 139-140.

7 O. Demchuk i in., Mechanizm transmisji polityki pieniężnej w Polsce. Co wiemy w 2011 roku? Raport, Instytut Ekonomiczny, Biuro Badań, 2011, s. 11.

8 Polska Agencja Rozwoju Przedsiębiorczości, Raport o stanie sektora małych i średnich przed- 
nia jest wysoki poziom wykorzystania kredytów bankowych w sektorze przedsiębiorstw, co z kolei wiąże się ze stosunkowo silnym uzależnieniem od polityki pieniężnej banku centralnego.

Kreowanie impulsów za pośrednictwem kanału stopy procentowej znajduje odzwierciedlenie we wzroście bądź spadku krótkoterminowych stóp procentowych rynku międzybankowego. To z kolei stymuluje zmiany oprocentowania zarówno kredytów, jak i depozytów banków komercyjnych oraz dłużnych papierów wartościowych - korporacyjnych oraz rządowych. Biorąc pod uwagę obserwowaną w gospodarce lepkość cen, powoduje to zmianę realnych stóp procentowych, stymulując (bądź ograniczając) tym samym popyt przedsiębiorstw na kredyt ${ }^{9}$.

Rozpatrując to zagadnienie w kontekście struktury kapitałowej przedsiębiorstw, istotne znaczenie ma koszt kapitału, który rośnie bądź spada w zależności od stosowanych w danym momencie parametrów polityki monetarnej. Powoduje to zmiany w sposobie doboru źródeł finansowania działalności podmiotów gospodarczych, z uwzględnieniem ujemnej korelacji pomiędzy wysokością stóp procentowych a poziomem zadłużenia. Wysokość stóp procentowych jest również czynnikiem determinującym zakres prowadzonej działalności inwestycyjnej. Wysokie stopy procentowe zniechęcają przedsiębiorstwa do podejmowania kosztochłonnych inwestycji, co dodatkowo obniża zapotrzebowanie na dłużne instrumenty finansowania.

Odrębnym mechanizmem jest kanał kredytowy, który przejawia się w oddziaływaniu zmian stóp procentowych na podaż kredytu. Wyróżnia się przy tym kanały dotyczące bilansów banków oraz pozostałych podmiotów gospodarczych. W pierwszym przypadku chodzi o kanał kredytów i pożyczek bankowych. Bank centralny, dokonując zmian stóp procentowych, wpływa na poziom płynnych rezerw banków komercyjnych oraz determinuje możliwości refinansowania prowadzonej przez nie akcji kredytowej. Zaostrzenie polityki pieniężnej obniża zatem podaż kredytu, ograniczając tym samym jego dostępność w sektorze przedsiębiorstw, co znajduje odbicie w strukturach kapitałowych. Natomiast mechanizm kanału bilansowego odzwierciedla wpływ zmian stóp procentowych na wartość aktywów stanowiących potencjalne zabezpieczenie środków kredytowych. Wzrost stóp procentowych powoduje spadek tej wartości, co z kolei obniża zdolność do zabezpieczenia kredytów, wywołując zjawisko tzw. negatywnej selekcji, a także pokusy nadużycia (moral hazard). W efekcie może to prowadzić do obniżenia skłonności banków do kredytowania sektora przedsiębiorstw.

Istnieje szereg czynników warunkujących skuteczność oddziaływania wysyłanych przez bank centralny impulsów monetarnych. Należą do nich: struktura popytu krajowego, stopień otwartości gospodarki, jak również struktura finansowa

siębiorstw w Polsce w latach 2013-2014, Warszawa 2015, s. 13.

9 A. Białek-Jaworska, Wpływ polityki monetarnej na źródła finansowania przedsiębiorstw w Polsce w latach 1995-2012, Materiały i Studia nr 304, Narodowy Bank Polski, Instytut Ekonomiczny, Warszawa 2014, s. 94. 
gospodarki znajdująca odzwierciedlenie w rodzajach źródeł finansowania przedsiębiorstw oraz gospodarstw domowych. Są to także cechy związane bezpośrednio z systemem bankowym, takie jak: jego struktura własnościowa, stopień koncentracji czy struktura bilansów banków ${ }^{10}$.

\subsection{Wpływ polityki monetarnej na strukturę kapitałową przedsiębiorstw w świetle przeprowadzonych badań}

W kontekście kształtowania parametrów polityki monetarnej istotne znaczenie mają bieżąca sytuacja gospodarcza kraju oraz oczekiwania w tym zakresie. Warto tym samym dokonać diagnozy tej sytuacji z uwzględnieniem wybranych wskaźników makroekonomicznych.

Analizowany okres charakteryzował się stosunkowo dobrą kondycją polskiej gospodarki. Przede wszystkim odnotowano wzrost produktu krajowego brutto oraz wartości dodanej brutto. W ujęciu cen bieżących wzrost ten wyniósł odpowiednio: $26,2 \%$ oraz $26,1 \%$. Wzrosła również ogólna wartość nakładów inwestycyjnych - z 218,6 mld zł w 2009 roku do 250,8 mld zł w roku 2014. Ponadto poprawie uległa sytuacja na rynku pracy, czego wyrazem był wzrost liczby osób zatrudnionych oraz spadek stopy bezrobocia. Na uwagę zasługuje też rosnąca wartość eksportu oraz importu. W całym badanym okresie wzrost ten wyniósł odpowiednio: $63,8 \%$ oraz $52,1 \%$.

Bieżąca sytuacja gospodarcza nie pozostawała bez wpływu na kondycję finansową przedsiębiorstw. Badany okres charakteryzował się ogólną tendencją wzrostową przychodów ze sprzedaży, wyników finansowych, rentowności, jak również nakładów inwestycyjnych.

Analizując sytuację gospodarczą kraju w kontekście polityki monetarnej banku centralnego, szczególną uwagę należy zwrócić na zjawiska inflacyjne. W latach 2009-2011 odnotowano wzrost wskaźnika inflacji ze 103,5 do 104,3. Natomiast odmienna tendencja była obserwowana w podokresie 2012-2014, w którym wskaźnik uległ obniżeniu do poziomu 100,0 $0^{11}$.

Opisane tendencje zjawisk inflacyjnych znalazły swoje odzwierciedlenie w kształtowaniu parametrów polityki monetarnej banku centralnego, w tym wysokości stóp procentowych. Dane liczbowe przedstawiono na rysunku 7.1.

10 R. Kokoszczyński, T. Łyziak, E. Wróbel, Czynniki strukturalne we wspótczesnych teoriach mechanizmów transmisji polityki pieniężnej, „Bank i Kredyt” 2002, nr 11-12, s. 41.

11 Dane Głównego Urzędu Statystycznego, http://stat.gov.pl/wskazniki-makroekonomiczne/ (dostęp: 26.04.2016). 
Rysunek 7.1. Stopy procentowe Narodowego Banku Polskiego oraz rynkowe stopy procentowe w latach 2009-2014
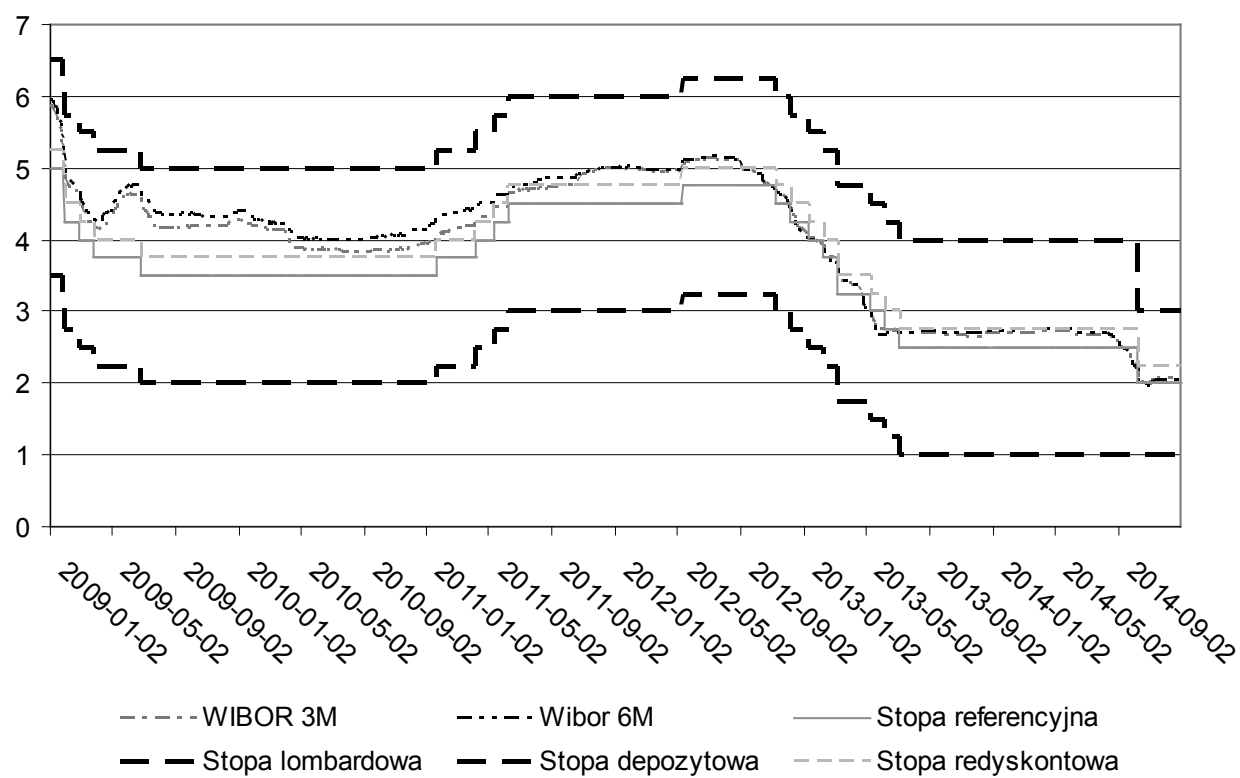

Źródto: opracowanie własne na podstawie danych Narodowego Banku Polskiego oraz portalu Money.pl (dostęp: 26.04.2016).

Rysunek 7.2. Wartość portfela kredytowego banków z tytułu kredytów udzielonych małym, średnim oraz dużym przedsiębiorstwom w latach 2009-2014 (w mld zt)

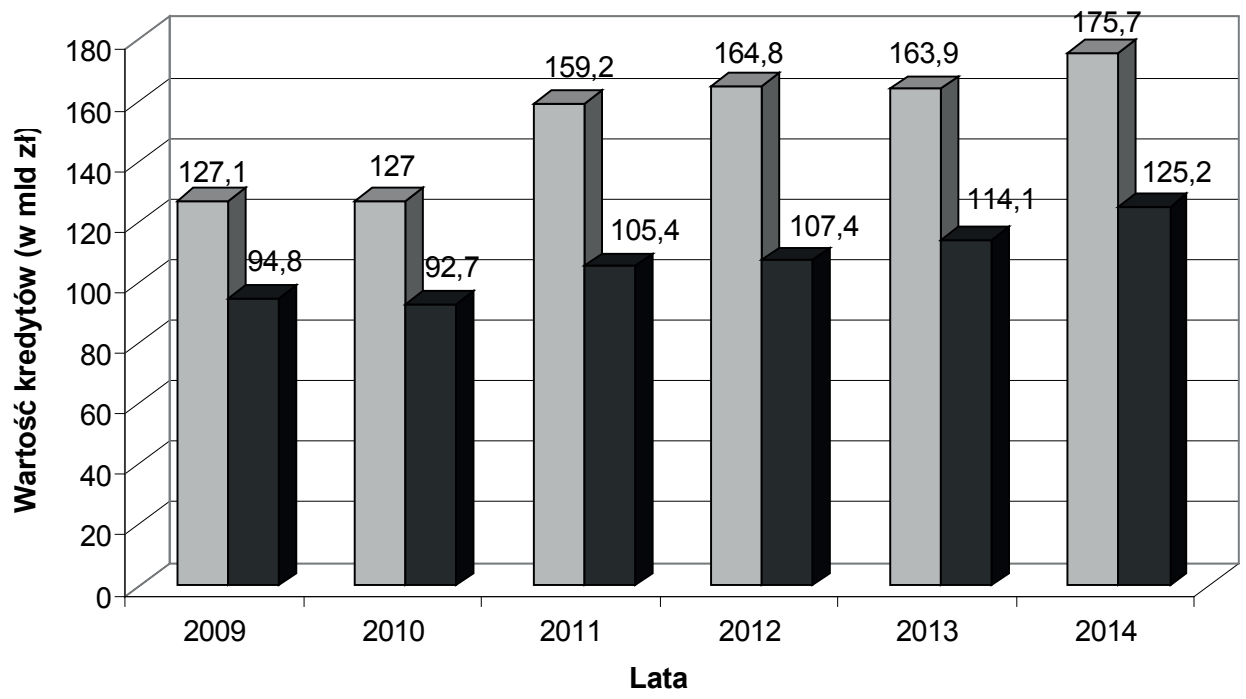

$\square$ MSP $\square$ Duże przedsiębiorstwa

Źródło: opracowanie własne na podstawie danych Komisji Nadzoru Finansowego. 
Badany okres cechował się dość wyraźną zmiennością stóp procentowych. Po początkowym spadku w 2009 roku oraz stabilizacji w 2010 roku nastąpił wzrost stóp procentowych trwający do maja 2012 roku. W kolejnych podokresach nastąpił znaczący spadek badanych wielkości. Trend ten jest szczególnie widoczny w okresie od listopada 2012 do lipca 2013 roku.

Odnotowane tendencje znalazły odzwierciedlenie $\mathrm{w}$ zmienności rynkowych stóp procentowych, $\mathrm{w}$ tym WIBOR $3 \mathrm{M}$ oraz WIBOR $6 \mathrm{M}$. Stopy te należą do najczęściej stosowanych przy ustalaniu wysokości oprocentowania kredytów, pożyczek, obligacji czy innych instrumentów finansowania działalności przedsiębiorstw. Dane zawarte na rysunku 7.1 wskazują też na dość silną zależność występującą pomiędzy stopami procentowymi banku centralnego a stopami rynkowymi. Tym samym poziom oraz zmienność stóp procentowych NBP stanowi jeden $z$ kluczowych czynników warunkujących koszt i dostępność kapitałów zewnętrznych, a w szczególności kredytu bankowego. Dane liczbowe obrazujące wartość kredytów dla przedsiębiorstw w Polsce przedstawiono na rysunku 7.2.

Dane liczbowe wskazują na zróżnicowane tendencje zmian wartości portfela kredytowego banków. W latach 2009-2010 nastąpił nieznaczny (1\%) spadek łącznej wartości kredytów. Spadek ten odnotowano zarówno w grupie małych i średnich przedsiębiorstw, jak i dużych podmiotów gospodarczych. W kolejnych okresach obserwowana była dość wyraźna tendencja wzrostowa wartości portfela kredytowego. W ujęciu łącznym wartość ta wzrosła o niemal 37\% (z 219,7 mld zł w 2010 r. do 300,9 mld zł w roku 2014).

Najwyższe tempo wzrostu odnotowano w podokresach 2010-2011 (20,4\%) oraz 2013-2014 (8,2\%). Warto zauważyć, że okresy te poprzedzone były obniżką stóp procentowych i stosunkowo długim okresem utrzymania ich na relatywnie niskim poziomie. Taki stan rzeczy potwierdza obserwowany $\mathrm{w}$ gospodarce efekt opóźnienia akcji kredytowej banków w stosunku do zmian parametrów polityki monetarnej. Wydaje się również potwierdzać istotny wpływ zmienności procentowych na wartość kredytów udzielonych przedsiębiorstwom.

Biorąc pod uwagę istotną rolę kredytu bankowego w procesie finansowania przedsiębiorstw, zmiany parametrów polityki pieniężnej powinny znaleźć swoje odzwierciedlenie w strukturach kapitałowych. Dane liczbowe obrazujące wartość wybranych wskaźników przedstawiono na rysunku 7.3.

Uszczegółowieniem danych zawartych na rysunku 7.3 są wyniki analizy struktury kapitałowej z uwzględnieniem kryterium wielkości przedsiębiorstw (tab. 7.1):

Dane liczbowe wskazują na zróżnicowane tendencje zmian struktury kapitałowej. W latach 2009-2011 przedsiębiorstwa zwiększyły poziom zadłużenia, czego przejawem był wzrost wskaźników: ogólnego zadłużenia oraz zadłużenia kapitału własnego. W kolejnych okresach trend ten uległ odwróceniu. Wyjątek stanowił jedynie wskaźnik zadłużenia długoterminowego kapitału własnego, który w latach 2011-2014 wzrósł o 2,9 p.p. Obserwowane tendencje cechowały przede wszystkim małe i średnie przedsiębiorstwa. Odmienną sytuację zaobserwowano natomiast w sektorze dużych podmiotów gospodarczych, gdzie wskaźniki miały dość wyraźną tendencję wzrostową w niemal całym analizowanym okresie. 
Wpływ polityki monetarnej na strukturę kapitałową przedsiębiorstw...

Rysunek 7.3. Wskaźniki struktury kapitałowej przedsiębiorstw w Polsce w latach 2009-2014 (w \%)

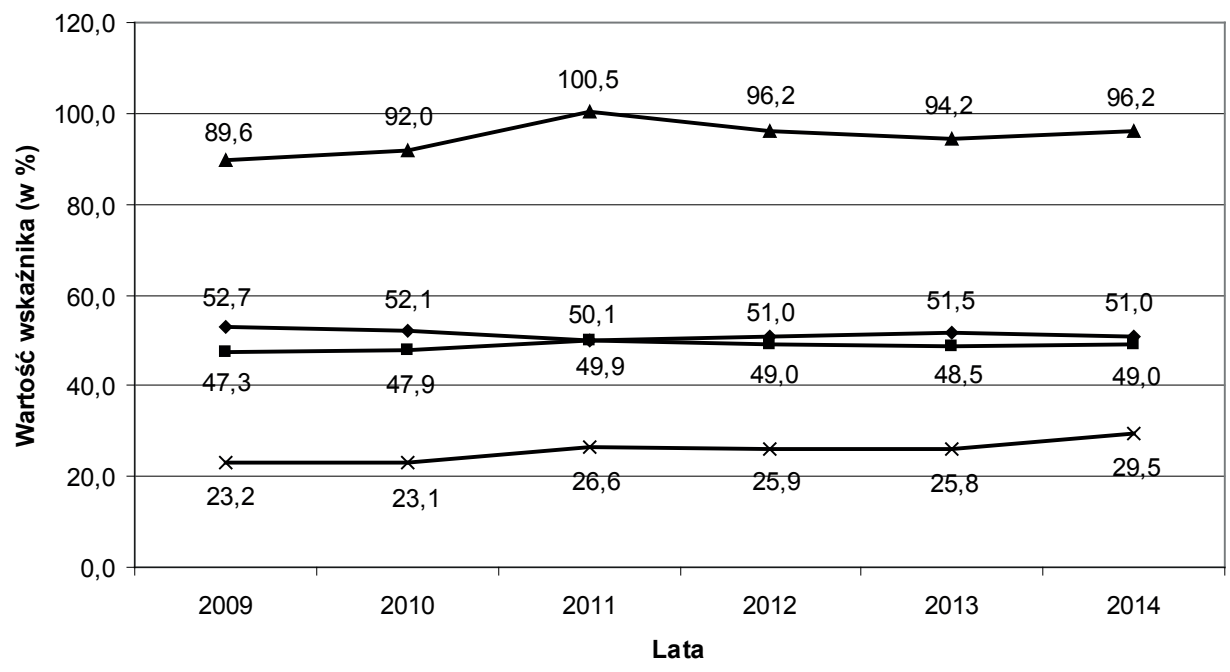

\footnotetext{
$\longrightarrow$ —Udział kapitału własnego w finansowaniu aktywów $\rightarrow$-Ogólne zadłużenie

$\rightarrow$ Zadłużenie kapitału własnego $\quad *$ Zadłużenie długoterminowe kapitału własnego
}

Źródło: opracowanie własne na podstawie danych Głównego Urzędu Statystycznego.

Tabela 7.1. Wskaźniki struktury kapitałowej z podziałem na małe, średnie oraz duże przedsiębiorstwa (w \%)

\begin{tabular}{|c|c|c|c|c|c|c|}
\hline \multirow{2}{*}{$\begin{array}{l}\text { Wyszczególnie- } \\
\text { nie }\end{array}$} & \multicolumn{6}{|c|}{ Lata } \\
\hline & 2009 & 2010 & 2011 & 2012 & 2013 & 2014 \\
\hline \multicolumn{7}{|c|}{ Udział kapitału własnego w finansowaniu aktywów } \\
\hline MSP & 52,3 & 49,9 & 45,9 & 48,3 & 49,9 & 49,9 \\
\hline $\begin{array}{l}\text { Duże } \\
\text { przedsiębiorstwa }\end{array}$ & 53,0 & 53,5 & 52,3 & 52,6 & 52,4 & 51,6 \\
\hline \multicolumn{7}{|c|}{ Ogólne zadłużenie } \\
\hline MSP & 47,7 & 50,1 & 54,1 & 51,7 & 50,1 & 50,1 \\
\hline $\begin{array}{l}\text { Duże } \\
\text { przedsiębiorstwa }\end{array}$ & 47,0 & 46,5 & 47,7 & 47,4 & 47,6 & 48,4 \\
\hline \multicolumn{7}{|c|}{ Zadłużenie kapitału własnego } \\
\hline MSP & 91,2 & 100,4 & 118,1 & 107,2 & 100,3 & 100,3 \\
\hline $\begin{array}{l}\text { Duże } \\
\text { przedsiębiorstwa }\end{array}$ & 88,6 & 87,0 & 91,2 & 90,0 & 90,8 & 93,8 \\
\hline \multicolumn{7}{|c|}{ Zadłużenie długoterminowe kapitału własnego } \\
\hline MSP & 24,2 & 26,2 & 30,9 & 29,5 & 27,1 & 29,2 \\
\hline $\begin{array}{l}\text { Duże } \\
\text { przedsiębiorstwa }\end{array}$ & 22,6 & 21,3 & 24,4 & 23,8 & 25,1 & 29,7 \\
\hline
\end{tabular}

Źródło: opracowanie własne na podstawie danych Głównego Urzędu Statystycznego. 
Trzeba przy tym pamiętać o relatywnie wysokim poziomie zadłużenia sektora MSP. W przeciwieństwie do dużych podmiotów gospodarczych kapitał obcy stanowił tu wiodącą formę finansowania działalności. Efektem tego stanu rzeczy jest większa wrażliwość tej grupy podmiotów gospodarczych na zmianę parametrów polityki pieniężnej, w tym zmienność stóp procentowych.

Przeprowadzona analiza pozwala zaobserwować dość silną zależność pomiędzy kształtowaniem się stóp procentowych a zmiennością struktur kapitałowych przedsiębiorstw. Wzrostowy trend wskaźników zadłużenia odnotowano w okresach spadku stóp procentowych i utrzymywania się ich na stosunkowo niskim poziomie. Chodzi tu o lata 2009-2011 oraz rok 2014. Uzasadnione jest zatem twierdzenie o ujemnej korelacji pomiędzy zmiennością stóp procentowych a poziomem zadłużenia, opisywane w literaturze przedmiotu. Zjawisko to dotyczy nie tylko kredytu bankowego, ale również innych instrumentów pozyskiwania kapitału, w tym leasingu, faktoringu, kredytu handlowego, dłużnych papierów wartościowych czy też pożyczek pozabankowych. Potwierdzeniem tej tezy są dane statystyczne. Dla przykładu wartość środków trwałych oddanych w leasing wzrosła w latach 2009-2011 o $32,6 \%{ }^{12}$, natomiast wartość przeprowadzonych transakcji faktoringowych o $54,6 \%{ }^{13}$.

Z przeprowadzonych analiz wynika, że stopy procentowe stanowią istotny parametr w kształtowaniu struktur kapitałowych przedsiębiorstw. Zmiany parametrów polityki monetarnej w tym zakresie wpływają na decyzje przedsiębiorców odnośnie wyboru źródeł i instrumentów finansowania. Odzwierciedleniem tych decyzji jest zmienność struktur kapitałowych charakteryzująca się wzrostem bądź spadkiem zadłużenia. Tym samym kanał stóp procentowych należy uznać za istotny mechanizm oddziaływania banku centralnego na struktury kapitałowe przedsiębiorstw.

\section{Podsumowanie}

Jednym z kluczowych problemów zarządzania finansami firm jest odpowiedni dobór źródeł oraz instrumentów finansowania działalności. Celem decyzji oraz działań podjętych w tym zakresie jest optymalizacja struktury kapitałowej przedsiębiorstwa.

Istnieje szereg determinant struktury kapitałowej. Z jednej strony są to czynniki wewnętrzne związane ze specyfiką danego przedsiębiorstwa, $z$ drugiej - czynniki zewnętrzne związane z szeroko rozumianym otoczeniem (mikro- bądź makroekonomicznym), w którym ono funkcjonuje. Na szczególną uwagę zasługuje tu

12 Dane Związku Polskiego Leasingu, www.leasing.org.pl (dostęp: 26.04.2016).

13 Tamże. 
polityka pieniężna banku centralnego, która na strukturę kapitałową przedsiębiorstwa może oddziaływać poprzez mechanizm kredytowy, kursu walutowego, cen aktywów, stopy procentowej, a także kanały niestandardowe. Przedmiotem badań w niniejszym artykule był kanał stopy procentowej.

Wyniki przeprowadzonych analiz wskazały na istotną zależność pomiędzy zmiennością stóp procentowych banku centralnego a strukturami kapitałowymi przedsiębiorstw. Wzrostowi bądź też spadkowi tych wielkości towarzyszyły zmiany analizowanych wskaźników finansowych (wzrost lub spadek zadłużenia oraz wyposażenia przedsiębiorstwa w kapitały własne). Potwierdzeniem tych konstatacji są również tendencje obserwowane na rynkach poszczególnych instrumentów finansowych, w tym kredytów bankowych, leasingu oraz faktoringu.

Polityka pieniężna (w tym kształtowanie stóp procentowych) stanowi jeden z wielu czynników determinujących strukturę kapitałową przedsiębiorstw. Błędem byłoby więc w sposób jednoznaczny i kategoryczny wnioskować o doborze instrumentów finansowania, biorąc pod uwagę wyłącznie zmienność parametrów w tym zakresie. Należy jednak podkreślić, że to właśnie polityka monetarna stanowi kluczowy czynnik determinujący koszt kapitału, jego dostępność, a w konsekwencji rentowność prowadzonej działalności oraz wartość przedsiębiorstwa.

\section{Bibliografia}

Białek-Jaworska A., Wpływ polityki monetarnej na źródła finansowania przedsiębiorstw w Polsce w latach 1995-2012, Materiały i Studia nr 304, Narodowy Bank Polski, Instytut Ekonomiczny, Warszawa 2014.

Demchuk O. i in., Mechanizm transmisji polityki pieniężnej w Polsce. Co wiemy w 2011 roku? Raport, Instytut Ekonomiczny, Biuro Badań, 2011.

Ickiewicz J., Pozyskiwanie, koszt i struktura kapitału w przedsiębiorstwach, Szkoła Główna Handlowa w Warszawie, Warszawa 2004.

Kokoszczyński R., Łyziak T., Wróbel E., Czynniki strukturalne we współczesnych teoriach mechanizmów transmisji polityki pieniężnej, „Bank i Kredyt” 2002, nr 11-12.

Kubiak J., Metody badania asymetrii informacji w przedsiębiorstwie w zakresie alokacji kapitału, „Gospodarka Narodowa" 2011, nr 4 (236).

Łach K., Kierunki badań nad determinantami struktury kapitału przedsiębiorstw w Polsce, Polskie Towarzystwo Ekonomiczne, Zeszyty Naukowe nr 12, Kraków 2012.

Mokhova N., Zinecker M., Macroekonomic factors and corporate capital structure, „Procedia - Social and Behavioral Sciences" 2014, No. 110.

Myers S.C., The Capital Structure Puzzle, „The Journal of Finance" 1984, Vol. XXXIX, No. 3.

Przybylska-Kapuścińska W., Impulsy i instrumenty monetarne $w$ ksztattowaniu relacji między bankiem centralnym a sektorem bankowym, „Ruch Prawniczy, Ekonomiczny i Socjologiczny” 2008, z. 2.

Polska Agencja Rozwoju Przedsiębiorczości, Raport o stanie sektora małych i średnich przedsiębiorstw w Polsce w latach 2013-2014, Warszawa 2005. 


\title{
WPŁYW POLITYKI MONETARNEJ NA STRUKTURĘ KAPITAŁOWĄ PRZEDSIĘBIORSTW W POLSCE
}

\section{Streszczenie:}

W opracowaniu podjęto problematykę wpływu polityki pieniężnej banku centralnego na strukturę kapitałową przedsiębiorstw w Polsce. Zakresem przedmiotowym badań objęto kanał stóp procentowych jako jeden z głównych mechanizmów transmisji impulsów polityki monetarnej. Wyniki przeprowadzonych analiz wskazały na istotny związek pomiędzy zmiennością stóp procentowych banku centralnego a strukturami kapitałowymi polskich przedsiębiorstw. Związek ten zaobserwowano również w odniesieniu do poszczególnych segmentów rynku finansowego stanowiących źródło finansowania działalności przedsiębiorstw. Ponadto potwierdzono tezę o ujemnej zależności pomiędzy wysokością stóp procentowych a poziomem zadłużenia przedsiębiorstw.

Słowa kluczowe: polityka monetarna, struktura kapitałowa przedsiębiorstwa, stopa procentowa

\section{THE IMPACT OF MONETARY POLICY ON ENTERPRISES CAPITAL STRUCTURE IN POLAND}

\author{
Summary: \\ The article concerns a problem of impact of monetary policy on enterprises capital structure \\ in Poland. The scope of research included interest rate channel as one of the basic mechanism \\ of monetary transmission. The results of analysis indicates significant relationship between volatility \\ of central bank interest rates and polish enterprises capital structures. This kind of relationship was \\ also observed in the area of particular segments of financial market, that are sources of financing \\ of enterprises activity. Moreover negative correlation between a level of interest rates and enterprises \\ debt, has been confirmed.
}

Keywords: monetary policy, enterprise capital structure, interest rate 